\title{
Teachers' Teaching Practice and Student Achievement in Basic Economics-A Comparison in Two Types of Schools in Malaysia
}

\author{
Termit Kaur Ranjit Singh ${ }^{1} \&$ Sashi Kala Krishnan ${ }^{1}$ \\ ${ }^{1}$ School of Educational Studies, Universiti Sains Malaysia, Malaysia \\ Correspondence: Termit Kaur Ranjit Singh, School of Educational Studies, Universiti Sains Malaysia, Malaysia. \\ E-mail: termitk@gmail.com
}

Received: August 1, 2014 Accepted: September 22, 2014 Online Published: October 29, 2014

doi:10.5539/ies.v7n11p162 URL: http://dx.doi.org/10.5539/ies.v7n11p162

\begin{abstract}
The purpose of this study is to compare teachers' teaching practice based on students' perception towards achievement in the subject of Basic Economics between two different types of secondary schools in Malaysia, the National Secondary Schools (SMK) and Chinese National Type Secondary Schools (SMJK) in the state of Penang, Malaysia. The respondents involved in this study consist of 12517 year old students from four SMK schools and 125 students from three SMJK schools in Penang. Survey method was employed in the data collection. The quantitative data obtained was analysed using the SPSS. The research shows that there are significant differences between SMK and SMJK in terms of teachers' teaching practice towards Basic Economics. The result of correlation analysis indicates that correlation between teachers' teaching practice and the students' achievement in SMK is significant unlike in SMJK.
\end{abstract}

Keywords: basic economics, students' achievement, teachers' teaching practice, secondary national schools, secondary national type schools

\section{Introduction}

Malaysia's education system aims to produce a balanced student physically, emotionally, intellectually, and spiritually so that they can serve as productive citizens who are able to support the vision and mission of the country. In connection with the government's interest, one of the agenda of the Ministry of Education (MOE) is to strengthen all National Schools or 'Sekolah Kebangsaan' (SK), since SK was established as a vehicle for unity among the various races. SK serving as a place for young people to live in community, working together to achieve the vision of State (Ministry of Education, 2006). The Chinese National Type Secondary Schools (SMJK) are schools with Chinese being the main language and students who are also almost all of the chinese race.In general Malaysian education system is exam oriented and often used as an important indicator in determining the career of students and a school performance success. Comparison of students' performance between SMK and SMJK has always been a reference material and widely reported in the media. This can be seen each time a national exam results are announced. Generally the SMJK will fare better than SMK although both schools are well equipped equally with good infrastructure and trained teachers provided by the government. Most of the Chinese parents enroll their children in SMJK schools as Mandarin language is offered as a compulsory subject where else in SMK the subject is only offered as an optional subject. As a result SMJK is consists mainly of Chinese and a very few Malay and Indian students where else in SMK schools consists mainly of Malay and Indian students and a very few Chinese. In accordance with the goals and objectives of the MOE, Basic Economics was made as an elective subject in group II (Vocational and Technology) to Form Four and Form Five students in all the secondary schools. This subject was introduced in 1991/1992 as an experiment and the first group of students sat for the Sijil Pelajaran Malaysia (SPM) officially in 1994. The shortfall in the Higher Certificate Examination Malaysia (STPM) and at the same time the dwindling number of students taking this subject (Faridah, 1999) led to the introduction of the subject at Form Four and Form Five level. Many students are of the opinion that Economics is a difficult subject to understand and this perception has become a hindrance for the student to excel in this subject. The status of Economics as an elective subject in schools has also led the students to become nonchalant in learning and teaching process of the subject (Khoo \& Kassim, 2005). The 'chalk and talk' is the common method of teaching used in classrooms with high number of students, hoping to complete the syllabus in a stipulated given time (Becker \& Watts, 2001). Situation in Malaysian schools are that 
students enter the class without proper preparation and the lack of discussion in the classroom resulted in many students just waiting for a response from the teacher instead (Khoo \& Kassim, 2005). The most important challenge is how to overcome the inability to provide an environment of teaching and learning in the classroom that is conducive to all. Based on these issues, this study focuses on the teaching methods practiced by the teachers and the achievements of secondary school students in the subject of Economics.

\section{Objectives of the Study}

The purpose of this study was to examine the academic achievement in Basic Economics between the students in National Secondary Schools (SMK) and National Type Chinese Secondary Schools (SMJK) in Malaysia. In addition, this study also examined whether there is a significant relationship between teachers teaching practices and the achievement of the students in Economics.

The specific objectives of study are as follows:

i. To identify the teachers teaching practices according to the students' perception at SMK and SMJK.

ii. To identify students achievement in Basic Economics at SMK and SMJK.

iii. To identify the relationship between the teachers teaching practices and the achievement of the students in Basic Economics at SMK and SMJK.

Based on these objectives, the following questions were derived:

i. To what extent the teachers practice the teaching of Basic Economics at SMK and SMJK?

ii. What is the result achieved by the SMK and SMJK students in Basic Economics?

iii. Does teaching practices influence the achievement of Basic Economics at SMK and SMJK?

\section{Conceptual Framework}

The basic theoretical framework of this study is based on the Heck and Marcoulides (1996) Model. Originally, the model was used to study the productivity of goods and services in an organization. They have tested several important aspects of organizational structure that can affect the productivity of the organization. They hypothesized that organizational culture consists of three interrelated dimensions: a) socio-cultural system in the organization b) the system in the organization c) beliefs and attitudes of individuals working in the organization. Then the model was used to study the organization of education and the environment to determine aspects of organizational structure that may influence student performance. Heck and Marcoulides (1996) have detected a number of factors that affect the academic achievement of students. Opportunities for learning derived from the structure of educational institutions and processes such as the size of the educational institutions, courses offered, class learning procedures, allocation and resources of the institution, distribution of the teaching load for lecturers, number of students allocated to a specific program, monitoring students' performance, and social relationships between lecturers and peer groups.

Figure 1 below presents the model Heck and Marcoulides (1996), which includes five aspects that affect a student's academic achievement and can be classified into three subsystems, namely socio-cultural, organizational processes and individual beliefs. The first component is the socio-cultural subsystem which refers to the perception of the organizational structure of the school (social structure of the school curriculum, course offered and student grouping). The second component is the process of organizing and dimension values (trust and school evaluation process in the classroom, confidence in the school environment and social relationships). The last component is the individual beliefs (attitudes of students). 


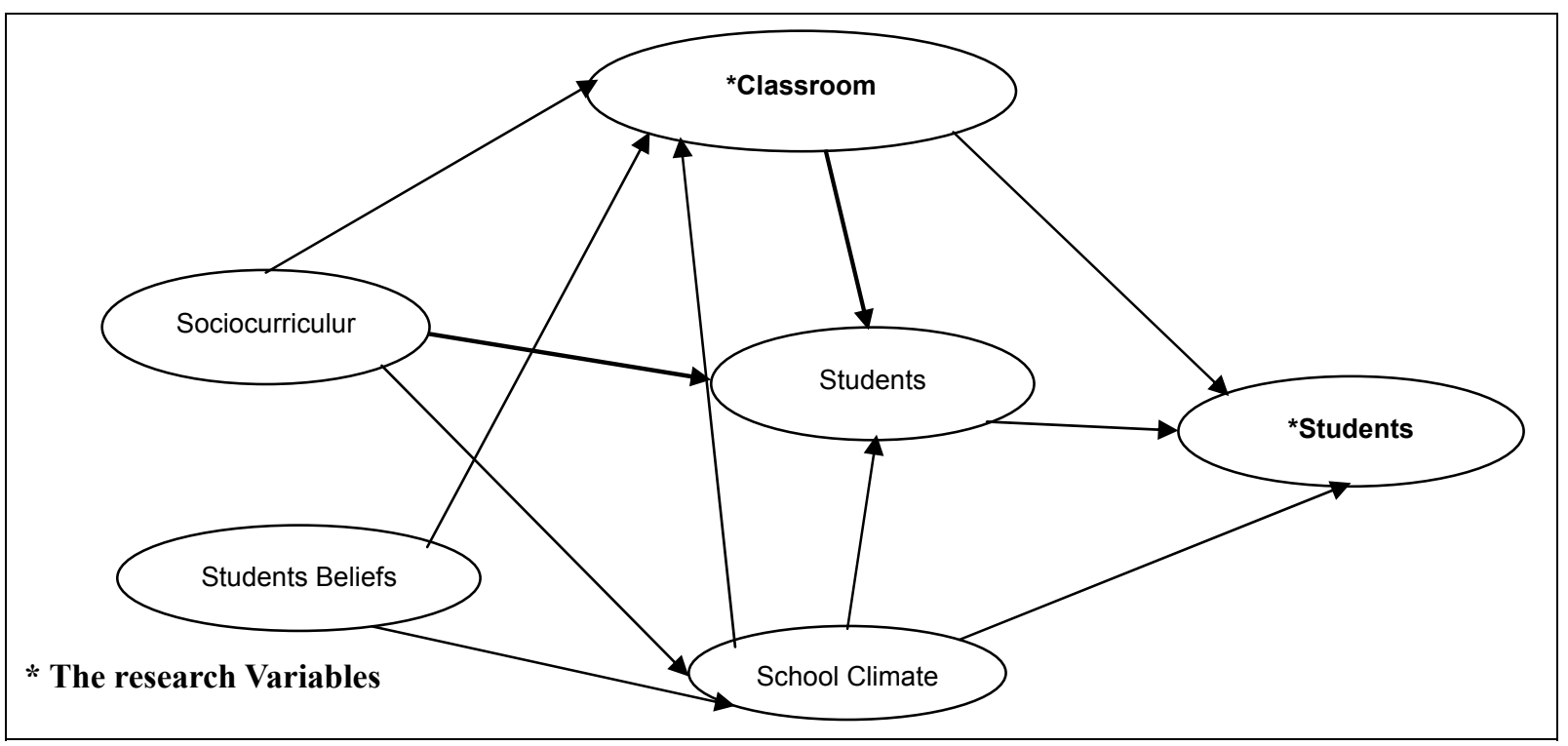

Figure 1. Source: model performance Heck and Marcoulides (1996)

Based on the model of academic achievement by Heck and Marcoulides, the researchers formed the framework to look into the aspects of the teaching process in the classroom that included teaching practice in determining academic achievement.

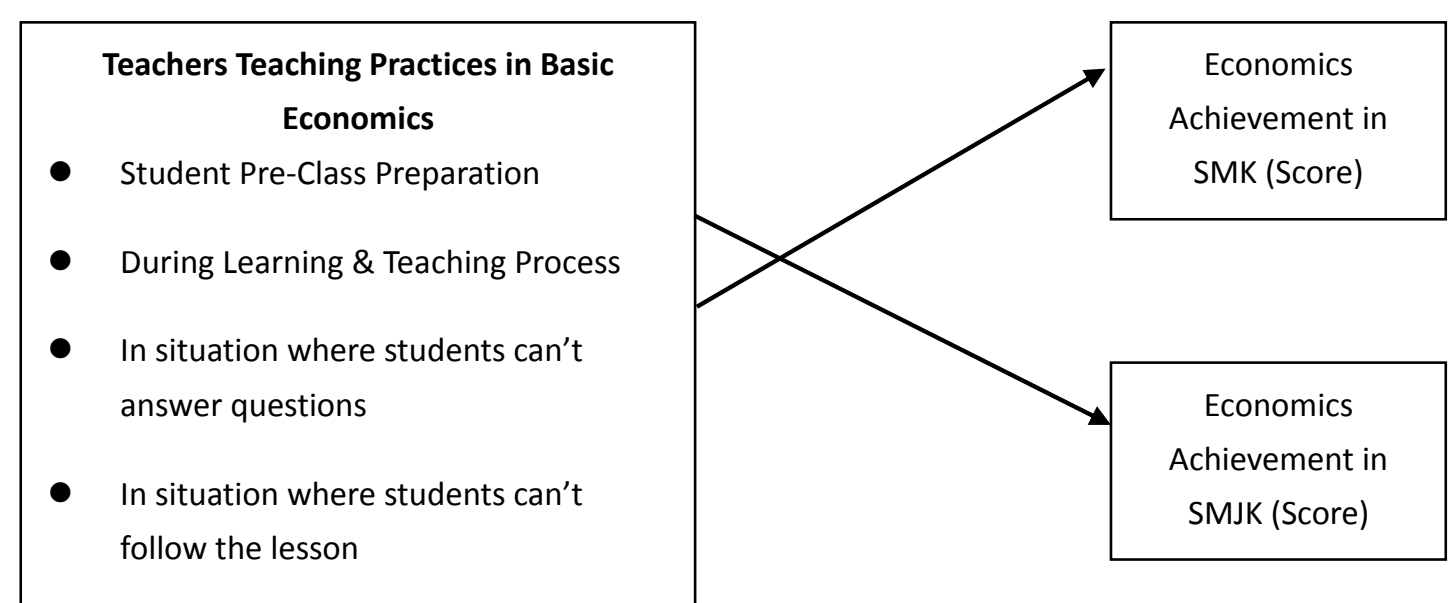

Figure 2. Conceptual framework of the study

Based on the conceptual framework study, independent variables and the dependent selected to build the model are taken into account in terms of logic and expediency while considering the relationship between them. Teachers teaching practices are based on the four dimensions that are ensuring student preparation before entering the classroom, during teaching and learning process in the classroom, in situation where students cannot answer questions and in situation where students cannot follow the lesson.

\section{Method}

\subsection{Research Design}

This was a comparative study between SMK and SMJK schools in Penang. The comparative variables were the teachers teaching practices and the students achievements in Basic Economics examination.

\subsection{Sampling}

The sample of this study involved respondents from SMK and SMJK secondary school students in Penang. Only control schools (schools with high achievers) were chosen to represent this two types of schools. This is done to 
avoid any bias and ensure samples from both groups are balanced. Four schools from SMK and three schools from SMJK were chosen to obtain same number of respondents from the two groups.

Table 1. Number of samples from each school

\begin{tabular}{cc}
\hline SMK Control Schools & Number of Samples (Form 5) \\
\hline SMK A & 30 \\
SMK B & 43 \\
SMK C & 30 \\
SMK D & 22 \\
\hline Total & 125 \\
\hline SMJK A & 61 \\
SMJK B & 35 \\
SMJK C & 29 \\
\hline Total & 125 \\
\hline
\end{tabular}

The Questionnaire was divided into three parts namely Part A, Part B and Part C. Part A consisted demographic characteristics Part B was the students' views and perceptions towards teachers' teaching practice of Basic Economics.

\subsection{Data Analysis}

Data obtained from the questionnaires was analyzed using descriptive statistics and inferential statistics. The students' perception of teachers' teaching practices were divided into three divisions that is high, medium and low. Distribution of mean scores and the level are shown in Table 2.

Table 2. Mean value and the level

\begin{tabular}{lc}
\hline Level & Mean \\
\hline High & 3.67 to 5.00 \\
Medium & 2.34 to 3.66 \\
Low & 1.00 to 2.33 \\
\hline
\end{tabular}

Descriptive analysis of items in teachers teaching practice in basic economics through student's perception:

The instrument consisted of four dimensions that are student pre-class preparation, during teaching and learning process in the classroom, in situation where students could not answer questions and in situation where students could not follow the lesson.

Mean Difference Score for Teachers Teaching Practice Dimension in Ensuring Student Pre-Class Preparation:

Table 3 below depicts that the total mean value for this dimension is high at 4.15 in SMK and 3.87 in SMJK. From this analysis we can conclude that student's perception in both types of school for teachers teaching practice in ensuring students pre-class preparation is very encouraging. 
Table 3. Mean difference score for teachers teaching practice dimension in ensuring student pre-class preparation

\begin{tabular}{|c|c|c|c|c|c|c|c|}
\hline \multirow[b]{2}{*}{$\begin{array}{l}\text { Teachers practice in } \\
\text { ensuring student pre-class } \\
\text { preparation }\end{array}$} & \multirow[b]{2}{*}{$\begin{array}{l}\text { School } \\
\text { Type }\end{array}$} & \multicolumn{6}{|c|}{ Scale } \\
\hline & & $\begin{array}{c}\text { Strongly } \\
\text { Agree }(\%)\end{array}$ & $\begin{array}{l}\text { Agree } \\
(\%)\end{array}$ & $\begin{array}{l}\text { Not } \\
\text { Sure } \\
(\%)\end{array}$ & $\begin{array}{l}\text { Disagree } \\
(\%)\end{array}$ & $\begin{array}{l}\text { Strongly } \\
\text { Disagree } \\
(\%)\end{array}$ & $\begin{array}{l}\text { Mean } \\
\text { Score } \\
\text { (SD) }\end{array}$ \\
\hline \multirow{4}{*}{$\begin{array}{l}\text { Teacher reminds students } \\
\text { to complete homework }\end{array}$} & & 42 & 63 & 17 & 3 & 0 & 4.15 \\
\hline & SMK & $(57.5)$ & $(47.4)$ & $(47.2)$ & $(42.9)$ & (0) & $(0.74)$ \\
\hline & SMJK & 31 & 70 & 19 & 4 & 1 & 4.01 \\
\hline & & $(42.5)$ & $(52.6)$ & $(52.8)$ & $(57.1)$ & $(100.0)$ & $(0.77)$ \\
\hline \multirow{4}{*}{$\begin{array}{l}\text { Teacher asks students to } \\
\text { review topics taught }\end{array}$} & SMK & 48 & 55 & 17 & 5 & 0 & 4.17 \\
\hline & SIVIR & (71.6) & $(49.5)$ & $(32.7)$ & $(33.3)$ & (0) & $(0.81)$ \\
\hline & SMIK & 19 & 56 & 35 & 10 & 5 & 3.59 \\
\hline & SIVIJ & $(28.4)$ & $(50.5)$ & $(67.3)$ & $(66.7)$ & $(100.0)$ & $(0.97)$ \\
\hline \multirow{4}{*}{$\begin{array}{l}\text { Teacher asks students to } \\
\text { make short notes on the } \\
\text { topics studied }\end{array}$} & SMK & 49 & 54 & 18 & 4 & 0 & 4.18 \\
\hline & & $(68.1)$ & $(51.9)$ & $(37.5)$ & $(18.2)$ & (0) & $(0.79)$ \\
\hline & SMJK & 23 & 50 & 30 & 18 & 4 & 3.56 \\
\hline & & (31.9) & $(48.1)$ & $(62.5)$ & $(81.8)$ & $(100.0)$ & $(1.00)$ \\
\hline \multirow{4}{*}{$\begin{array}{l}\text { Teacher asks students to } \\
\text { answer questions from the } \\
\text { topic studied }\end{array}$} & SMK & 44 & 57 & 19 & 4 & 1 & 4.11 \\
\hline & & $(45.8)$ & $(47.1)$ & $(73.1)$ & $(66.7)$ & $(100.0)$ & $(0.83)$ \\
\hline & SMJK & 52 & 64 & 7 & 2 & 0 & 4.33 \\
\hline & & $(54.2)$ & $(52.9)$ & $(26.9)$ & $(33.3)$ & (0) & $(0.65)$ \\
\hline \multirow{2}{*}{ Total Mean Value } & SMK & & & & & & 4.15 \\
\hline & SMJK & & & & & & 3.87 \\
\hline
\end{tabular}

Mean difference score for teachers teaching practice dimension during teaching and learning process in the classroom:

Table 4 below shows the total mean value score for teachers teaching practice dimension during teaching and learning process in the classroom is high at 4.31 in SMK and 4.08 in SMJK. Thus, the perception of students towards teachers teaching practice during teaching and learning in both types of school is very satisfactory. 
Table 4. Mean difference score for teachers teaching practice dimension during teaching and learning process in the classroom

\begin{tabular}{|c|c|c|c|c|c|c|c|}
\hline \multirow[b]{2}{*}{$\begin{array}{l}\text { Teachers practice during } \\
\text { teaching and learning } \\
\text { process in the classroom }\end{array}$} & \multirow[b]{2}{*}{$\begin{array}{l}\text { School } \\
\text { Type }\end{array}$} & \multicolumn{5}{|c|}{ Scale } & \multirow[b]{2}{*}{$\begin{array}{l}\text { Mean } \\
\text { Score } \\
\text { (SD) }\end{array}$} \\
\hline & & $\begin{array}{c}\text { Strongly } \\
\text { Agree (\%) }\end{array}$ & $\begin{array}{l}\text { Agree } \\
(\%)\end{array}$ & $\begin{array}{l}\text { Not } \\
\text { Sure } \\
(\%)\end{array}$ & $\begin{array}{c}\text { Disagree } \\
(\%)\end{array}$ & $\begin{array}{c}\text { Strongly } \\
\text { Disagree } \\
(\%)\end{array}$ & \\
\hline \multirow{4}{*}{$\begin{array}{l}\text { Teacher always ready } \\
\text { before starting a class }\end{array}$} & & 83 & 34 & 6 & 2 & 0 & 4.58 \\
\hline & SMK & $(55.0)$ & $(40.5)$ & $(54.5)$ & $(100.0)$ & $(0)$ & $(0.66)$ \\
\hline & SMJK & 68 & 50 & 5 & 0 & 2 & 4.46 \\
\hline & & $(45.0)$ & $(59.5)$ & $(45.5)$ & (0) & $(100.0)$ & $(0.72)$ \\
\hline \multirow{4}{*}{$\begin{array}{l}\text { Teacher always shows an } \\
\text { interest in teaching }\end{array}$} & & 83 & 32 & 9 & 0 & 1 & 4.57 \\
\hline & SMK & $(64.3)$ & $(34.4)$ & $(37.5)$ & (0) & $(33.3)$ & $(0.69)$ \\
\hline & SMJK & 46 & 61 & 15 & 1 & 2 & 4.18 \\
\hline & & $(35.7)$ & $(65.6)$ & $(62.5)$ & $(100.0)$ & $(66.7)$ & (0.79) \\
\hline \multirow{4}{*}{$\begin{array}{l}\text { Teacher always has a } \\
\text { control of the students } \\
\text { while teaching }\end{array}$} & & 54 & 57 & 13 & 1 & 0 & 4.31 \\
\hline & SMK & $(66.7)$ & $(50.4)$ & $(30.2)$ & $(100.0)$ & (0) & (0.68) \\
\hline & SMJK & 27 & 56 & 30 & 9 & 3 & 3.76 \\
\hline & & (33.3) & $(49.6)$ & $(69.8)$ & $(90.0)$ & $(100.0)$ & (0.94) \\
\hline \multirow{4}{*}{$\begin{array}{l}\text { Teacher uses various } \\
\text { method while teaching } \\
\text { Basic Economics }\end{array}$} & & 37 & 53 & 23 & 10 & 2 & 3.90 \\
\hline & SMK & $(84.1)$ & $(58.2)$ & (32.9) & (26.3) & $(28.6)$ & (0.97) \\
\hline & SMJK & 7 & 38 & 47 & 28 & 5 & 3.11 \\
\hline & & (15.9) & $(41.8)$ & $(67.1)$ & (73.7) & (71.4) & (0.95) \\
\hline \multirow{4}{*}{$\begin{array}{l}\text { Teacher uses method that } \\
\text { easily understood by the } \\
\text { students }\end{array}$} & & 31 & 59 & 25 & 10 & 0 & 3.89 \\
\hline & SMK & (43.7) & $(45.4)$ & (69.4) & (90.9) & $(0)$ & (0.87) \\
\hline & SMJK & 40 & 71 & 11 & 1 & 2 & 4.17 \\
\hline & & $(56.3)$ & $(54.6)$ & $(30.6)$ & (9.1) & (100.0) & $(0.74)$ \\
\hline \multirow{4}{*}{$\begin{array}{l}\text { Teacher never use the Basic } \\
\text { Economics period time to } \\
\text { teach other subjects }\end{array}$} & & 86 & 36 & 1 & 2 & 0 & 4.65 \\
\hline & SMK & (49.7) & $(56.3)$ & (20.0) & (33.3) & $(0)$ & (0.58) \\
\hline & SMJK & 87 & 28 & 4 & 4 & 2 & 4.55 \\
\hline & & $(50.3)$ & $(43.8)$ & $(80.0)$ & (66.7) & $(100.0)$ & $(0.83)$ \\
\hline \multirow{4}{*}{$\begin{array}{l}\text { Teacher well knowledge } \\
\text { and experience in } \\
\text { Economics }\end{array}$} & & 55 & 50 & 19 & 1 & 0 & 4.27 \\
\hline & SMK & $(47.8)$ & $(49.0)$ & $(65.5)$ & $(50.0)$ & (0) & $(0.74)$ \\
\hline & SMJK & 60 & 52 & 10 & 1 & 2 & 4.34 \\
\hline & & $(52.2)$ & $(51.0)$ & $(34.5)$ & $(50.0)$ & $(100.0)$ & (0.79) \\
\hline \multirow{2}{*}{ Total Mean Value } & SMK & & & & & & 4.31 \\
\hline & SMJK & & & & & & 4.08 \\
\hline
\end{tabular}

Mean difference score for teachers teaching practice dimension in situation where students could not answer questions:

Table 5 below shows the total mean value score for teachers teaching practice dimension in situation where students could not answer questions is high at 4.08 in SMK and 3.98 in SMJK. Thus, the perception of students towards teachers teaching practice in situation where students could not answer questions in both types of school is quite good. 
Table 5. Mean difference score for teachers teaching practice dimension in situation where students could not answer questions

\begin{tabular}{|c|c|c|c|c|c|c|c|}
\hline \multirow{2}{*}{$\begin{array}{l}\text { Teacher practice in } \\
\text { situation where students } \\
\text { could not answer questions }\end{array}$} & \multirow[b]{2}{*}{$\begin{array}{l}\text { School } \\
\text { Type }\end{array}$} & \multicolumn{5}{|c|}{ Scale } & \multirow[b]{2}{*}{$\begin{array}{l}\text { Mean } \\
\text { Score } \\
\text { (SD) }\end{array}$} \\
\hline & & $\begin{array}{c}\text { Strongly } \\
\text { Agree }(\%)\end{array}$ & $\begin{array}{l}\text { Agree } \\
(\%)\end{array}$ & $\begin{array}{l}\text { Not } \\
\text { Sure } \\
(\%)\end{array}$ & $\begin{array}{l}\text { Disagree } \\
(\%)\end{array}$ & $\begin{array}{c}\text { Strongly } \\
\text { Disagree } \\
(\%)\end{array}$ & \\
\hline \multirow{4}{*}{$\begin{array}{l}\text { Teacher shows the way to } \\
\text { answer the question step } \\
\text { by step }\end{array}$} & \multirow{2}{*}{ SMK } & 59 & 43 & 17 & 6 & 0 & 4.24 \\
\hline & & $(49.6)$ & $(44.3)$ & $(68.0)$ & $(85.7)$ & (0) & $(0.86)$ \\
\hline & \multirow[t]{2}{*}{ SMJK } & 60 & 54 & 8 & 1 & 2 & 4.35 \\
\hline & & $(50.4)$ & $(55.7)$ & $(32.0)$ & $(14.3)$ & $(100.0)$ & $(0.77)$ \\
\hline \multirow{4}{*}{$\begin{array}{l}\text { Teacher asks students to } \\
\text { refer to the given example }\end{array}$} & \multirow{2}{*}{ SMK } & 35 & 56 & 30 & 4 & 0 & 3.98 \\
\hline & & $(51.5)$ & $(50.9)$ & $(48.4)$ & $(50.0)$ & (0) & $(0.80)$ \\
\hline & \multirow{2}{*}{ SMJK } & 33 & 54 & 32 & 4 & 2 & 3.90 \\
\hline & & $(48.5)$ & $(49.1)$ & $(51.6)$ & $(50.0)$ & (100.0) & $(0.88)$ \\
\hline \multirow{4}{*}{$\begin{array}{l}\text { Teacher advises the } \\
\text { students to try their best to } \\
\text { answer }\end{array}$} & SMK & 64 & 44 & 14 & 2 & 1 & 4.34 \\
\hline & & $(66.7)$ & (39.6) & $(40.0)$ & $(33.3)$ & $(50.0)$ & $(0.80)$ \\
\hline & SMJK & 32 & 67 & 21 & 4 & 1 & 4.00 \\
\hline & & $(33.3)$ & $(60.4)$ & $(60.0)$ & $(66.7)$ & $(50.0)$ & $(0.79)$ \\
\hline \multirow{4}{*}{$\begin{array}{l}\text { Teacher asks the students } \\
\text { to meet him/her if they } \\
\text { could not understand }\end{array}$} & SMK & 32 & 44 & 38 & 10 & 1 & 3.77 \\
\hline & & $(58.2)$ & $(44.0)$ & $(53.5)$ & $(52.6)$ & $(20.0)$ & $(0.95)$ \\
\hline & SMJK & 23 & 56 & 33 & 9 & 4 & 3.68 \\
\hline & & $(41.8)$ & $(56.0)$ & $(46.5)$ & $(47.4)$ & $(80.0)$ & $(0.96)$ \\
\hline \multirow{2}{*}{ Total Mean Value } & SMK & & & & & & 4.08 \\
\hline & SMJK & & & & & & 3.98 \\
\hline
\end{tabular}

Mean difference score for teachers teaching practice dimension in situation where students could not follow the lesson:

Table 6 shows the total mean value score for teachers teaching practice dimension in situation where students could not follow the lesson is quite high at 4.13 in SMK and 3.92 in SMJK. Thus, the perception of students towards teachers teaching practice in situation where students could not follow the lesson in both types of school is satisfactory. 
Table 6. Mean difference score for teachers teaching practice dimension in situation where students could not follow the lesson

\begin{tabular}{|c|c|c|c|c|c|c|c|}
\hline \multirow[b]{2}{*}{$\begin{array}{l}\text { Teachers practice in } \\
\text { situation where students } \\
\text { could not follow the lesson }\end{array}$} & \multirow[b]{2}{*}{$\begin{array}{l}\text { School } \\
\text { Type }\end{array}$} & \multicolumn{5}{|c|}{ Scale } & \multirow[b]{2}{*}{$\begin{array}{l}\text { Mean } \\
\text { Score } \\
\text { (SD) }\end{array}$} \\
\hline & & $\begin{array}{l}\text { Strongly } \\
\text { Agree (\%) }\end{array}$ & $\begin{array}{l}\text { Agree } \\
(\%)\end{array}$ & $\begin{array}{l}\text { Not } \\
\text { Sure } \\
(\%)\end{array}$ & $\begin{array}{l}\text { Disagree } \\
(\%)\end{array}$ & $\begin{array}{l}\text { Strongly } \\
\text { Disagree } \\
(\%)\end{array}$ & \\
\hline \multirow{4}{*}{$\begin{array}{l}\text { Teacher repeats the lesson } \\
\text { until the students could } \\
\text { understand }\end{array}$} & SMK & 45 & 54 & 19 & 6 & 1 & 4.09 \\
\hline & & $(65.2)$ & $(45.4)$ & $(42.2)$ & $(50.0)$ & $(20.0)$ & $(0.88)$ \\
\hline & SMJK & 24 & 65 & 26 & 6 & 4 & 3.79 \\
\hline & & $(34.8)$ & $(54.6)$ & $(57.8)$ & $(50.0)$ & $(80.0)$ & $(0.91)$ \\
\hline \multirow{4}{*}{$\begin{array}{l}\text { Teacher advises the } \\
\text { students to pay full } \\
\text { attention while teaching }\end{array}$} & SMK & 60 & 49 & 15 & 1 & 0 & 4.34 \\
\hline & & $(60.0)$ & $(44.1)$ & $(45.5)$ & $(16.7)$ & $(0)$ & $(0.72)$ \\
\hline & SMJK & 40 & 62 & 18 & 5 & 0 & 4.10 \\
\hline & & $(40.0)$ & $(55.9)$ & $(54.5)$ & $(83.3)$ & $(0)$ & $(0.78)$ \\
\hline \multirow{4}{*}{$\begin{array}{l}\text { Teacher advises the } \\
\text { students to revise } \\
\text { repeatedly the topic to } \\
\text { understand better }\end{array}$} & SMK & 58 & 48 & 15 & 4 & 0 & 4.28 \\
\hline & & $(59.2)$ & $(45.7)$ & $(40.5)$ & $(44.4)$ & $(0)$ & $(0.79)$ \\
\hline & SMJK & 40 & 57 & 22 & 5 & 1 & 4.04 \\
\hline & & $(40.8)$ & $(54.3)$ & $(59.5)$ & $(55.6)$ & $(100.0)$ & $(0.85)$ \\
\hline \multirow{4}{*}{$\begin{array}{l}\text { Teacher uses alternative } \\
\text { ways to explain for the } \\
\text { students to understand } \\
\text { better }\end{array}$} & SMK & 24 & 61 & 34 & 6 & 0 & 3.82 \\
\hline & & $(43.6)$ & $(56.5)$ & $(48.6)$ & $(37.5)$ & $(0)$ & $(0.79)$ \\
\hline & SMJK & 31 & 47 & 36 & 10 & 1 & 3.78 \\
\hline & & $(56.40)$ & $(43.5)$ & (51.4) & $(62.5)$ & $(100.0)$ & $(0.94)$ \\
\hline \multirow{2}{*}{ Total Mean Value } & SMK & & & & & & 4.13 \\
\hline & SMJK & & & & & & 3.92 \\
\hline
\end{tabular}

Grades and basic economics mean scores at SMK and SMJK:

Based on Table 7, there were 92 students obtained grade A and out of it 17 students were from SMK (18.5\%) and 75 students were from SMJK (81.5\%). This reflects SMJK students gain excellent results in tests carried out. Number of students who received grade B in SMK was 51 students $(56.0 \%)$ and in SMJK were 40 students (44.0 \%) while the number of students who got a C is 52 students in SMK (83.9\%) and only 10 students in SMJK (16.1\%). No student got grade $\mathrm{E}$ in the test run. Table 7 also shows that the mean score for the Economics test achieved by the students of SMK is 3.64 and in SMJK is 4.52. Clearly, the test result shows that students' achievement in SMJK is far greater than students in SMK.

Table 7. Grades and mean score of the basic economics test result in SMK and SMJK

\begin{tabular}{ccccl}
\hline Grade & School Type & No. of Students & Percentage (\%) & \\
\hline \multirow{2}{*}{ A } & SMK & 17 & 18.5 & Score at SMK \\
& SMJK & 75 & 81.5 & Mean $=3.64$ \\
\multirow{2}{*}{ B } & SMK & 51 & 56.0 & SD $=0.766$ \\
& SMJK & 40 & 44.0 & $\mathrm{~N}=125$ \\
\hline \multirow{2}{*}{ C } & SMK & 52 & 83.9 & Score at SMJK \\
& SMJK & 10 & 16.1 & Mean $=4.52$ \\
D & SMK & 5 & 100.0 & SD $=0.643$ \\
& SMJK & 0 & 0 & $\mathrm{~N}=125$ \\
\hline Total & & 250 & 100 & \\
\hline
\end{tabular}


Table 8 shows the differences between the four dimensional of teachers teaching practices of Basic Economics in SMK and SMJK. The result of the test shows that all the dimension except for the dimension students could not answer question are less than the significant level of $\mathrm{P}<0.05$. Thus, it is concluded that there is significant differences between the dimensions.

Table 8. Difference in teachers teaching practice dimensions

\begin{tabular}{lccccccc}
\hline Item & $\mathrm{N}$ & Mean & Std. Deviation & Mean Difference & $\mathrm{t}$ & $\mathrm{df}$ & $\mathrm{p}$ \\
\hline \multicolumn{2}{l}{ Student pre-class preparation } \\
\hline SMK & 125 & 16.62 & 2.18 & 1.12 & 3.91 & 248 & 0.00 \\
SMJK & 125 & 15.49 & 2.36 & & & & \\
\hline During teaching \& learning & & & & & \\
\hline SMK & 125 & 30.17 & 2.98 & 1.60 & 3.73 & 248 & 0.00 \\
SMJK & 125 & 28.56 & 3.77 & & & & \\
\hline Student can't answer & & & & & \\
\hline SMK & 125 & 16.32 & 2.65 & & & & \\
SMJK & 125 & 15.92 & 2.52 & & & & \\
\hline Student can't follow lesson & & & & & \\
\hline SMK & 125 & 16.53 & 2.14 & & & & \\
\hline
\end{tabular}

Significance level at $\mathrm{P}<0.05$.

The $\mathrm{t}$ test in Table 9 shows the differences between students' evaluation of the Basic Economics teachers teaching practice in SMK and SMJK. Mean score of SMK is $79.65(\mathrm{~N}=125, \mathrm{SD}=8.05)$ in contrast to the mean score of SMJK is $75.68(\mathrm{~N}=125, \mathrm{SD}=9: 28)$. This shows the mean score of students in SMK is higher than the mean score of students in SMJK. The value of $t$ between schools is $t=3.61$ and value of $p$ is significant at $p=$ $0.00(\mathrm{P}<0.05)$.

Table 9. Difference between basic economics teachers teaching practice

\begin{tabular}{cccccccc}
\hline Item & $\mathrm{N}$ & Mean & Std. Deviation & Mean Difference & $\mathrm{t}$ & $\mathrm{df}$ & $\mathrm{p}$ \\
\hline SMK & 125 & 79.65 & 8.05 & 3.96 & 3.61 & 248 & 0.00 \\
SMJK & 125 & 75.68 & 9.28 & & & & \\
\hline
\end{tabular}

Significant level at $\mathrm{P}<0.05$.

Table 10 shows the relationship between the dimensions of teachers teaching practices and students achievement in Basic Economics at SMK and SMJK. The result of the test shows that all the dimension are more than the significant level of $\mathrm{P}=0.01$. Thus, it was concluded that there is no significant differences between the dimensions and the achievement of the students. 
Table 10. Correlation between the dimensions of teaching practice and students achievement in SMK and SMJK $(\mathrm{N}=250)$

\begin{tabular}{ccccccc}
\hline \multirow{2}{*}{ Item } & $\begin{array}{c}\text { Dimension } \\
1\end{array}$ & $\begin{array}{c}\text { Dimension } \\
2\end{array}$ & $\begin{array}{c}\text { Dimension } \\
\text { Dimension 1 } 1\end{array}$ & $\begin{array}{c}\text { Dimension } \\
4\end{array}$ & $\begin{array}{c}\text { Economics } \\
\text { Marks }\end{array}$ \\
\hline \multirow{2}{*}{ Dimension 2 } & Cearson & & $.475^{* *}$ & $.543^{* *}$ & $.561^{* *}$ & .004 \\
& Sig. (2-tailed) & & .000 & .000 & .000 & .953 \\
& $\begin{array}{c}\text { Pearson } \\
\text { Correlation }\end{array}$ & & & $.585^{* *}$ & $.572^{* *}$ & -.115 \\
& Sig. (2-tailed) & & .000 & .000 & .070 \\
\hline \multirow{2}{*}{ Dimension 3 } & Pearson & Correlation & & & $.686^{* *}$ & -.001 \\
& Sig. (2-tailed) & & & .000 & .987 \\
\hline \multirow{2}{*}{ Dimension 4 } & Pearson & & & & -.034 \\
& Correlation & & & & .591 \\
\hline
\end{tabular}

** Correlation is significant at the 0.01 level (2-tailed).

Hypothesis 4:

Table 11 shows the correlation between the score of teachers teaching practice and the students achievement in Basic Economics at SMK and SMJK. It shows that the correlation value in SMK is $\mathrm{r}=0.185$ and value $\mathrm{P}$ is $0.039(\mathrm{P}<0.05)$ while in SMJK, the correlation value is $\mathrm{r}=0.016$ and value $\mathrm{P}$ is $0.859(\mathrm{P}>0.05)$. From the result, we can conclude that there is a significant correlation between teachers teaching practice and the students achievement in SMK while in SMJK there is no significant correlation. Thus, the null hypothesis is rejected for SMK and accepted for SMJK. The table also shows overall score of the correlation and the value is $r=0.053$ and value $\mathrm{P}$ is not significant at $0.400(\mathrm{P}>0.05)$. Overall, there is no significant relationship between teachers teaching practice and the students' achievement in Basic Economics.

Table 11. Correlation (r) between teachers teaching practice and students basic economics performance

\begin{tabular}{lccc}
\hline \multirow{2}{*}{ Teaching Practice Variables } & \multicolumn{2}{c}{ Economics Marks } & \multirow{2}{*}{ Overall Score } \\
\cline { 2 - 3 } & SMK & SMJK & \\
\hline Pearson Correlation & $.185^{*}$ & .016 & -.053 \\
Sig.(2-tailed) & .039 & .859 & .400 \\
$\mathrm{~N}$ & 125 & 125 & 250
\end{tabular}

* Correlation is significant at the 0.05 level (2-tailed).

\section{Discussion}

Discussion of the study focused on the following aspects:

-Comparing Basic Economics teachers teaching practices in SMK and SMJK

-Comparison of the Economics test results in SMK and SMJK

-The relationship between teaching practice with the test results in SMK and SMJK

T-test analysis found that the overall mean value for the practices of teaching in SMK is $79.65(\mathrm{n}=125, \mathrm{SD}=$ $8.05)$ in contrast to a mean score of 75.68 in SMJK $(n=125, \mathrm{SD}=9.28)$. SMK students gave higher scores to their Basic Economics teachers' teaching practices than SMJK students. This finding is consistent with studies done by Arippin (2008) who found that students in primary level (SK) gave high scores to their teachers' teaching practices compared to students in SJK. The results also showed a significant value of $p=0.00(p<0.05)$. 
Therefore, this indicates that there is a significant mean difference of Basic Economics teachers teaching practices in SMK and SMJK.

The findings from the test results demonstrate that the performance of SMJK students were better than SMK students. This was further strengthened by looking at the performance of SMJK students whose mean score value is 4.52 while SMK students mean score is 3.64. This reflects students performance in SMJK were at high level compared to the SMK at the medium level.

The Pearson Correlation analysis shows that the relationship between teachers teaching practice and the students achievement in Basic Economics is significant in SMK while in SMJK is not significant. At the same time the test results indicates that SMJK students faired better than SMK students. Consequently, these findings suggest that the achievement of the students in Basic Economics were not influenced by students' perception of teachers teaching practice of the subject.

\section{Conclusion}

This study gives an indication of some of the issues and problems associated with the performance of students in Basic Economics and teachers' teaching practices on the subject. The result of the study indicates that students who gave high score to their teachers' teaching practice did fairly poorer than the students who gave lower scores to their teachers teaching practice. If we sum up all the dimensions of teachers teaching practices in relation to the performance of students in Basic Economics, results show there is a significant correlation $(r=0.185, p$ $<0.05)$ in SMK, while in SMJK there's no significant correlation $(r=0.016, p>0.05)$. This implies that student's perception on their teachers teaching practice and their performance in the Basic Economics is irrelevant. Consolidating a culture of learning among teachers is important to produce teachers who are really knowledgeable and professional. This professionalism is related to a change in the attitude to keep abreast of the latest teaching profession, knowing the theory and research findings and engage in research. Therefore, teachers need to change in line with the demands and the current scenario of the teaching and learning process of Basic Economics.

\section{Acknowledgements}

Supported by Short Term Grant (304/PGURU/6312017), Universiti Sains Malaysia.

\section{References}

Arippin, B. Y. (2008). Perbandingan keputusan ujian pencapaian sekolah rendah dan sikap pengajaran guru antara Sekolah Kebangsaan dengan Sekolah Jenis Kebangsaan Cina: Kajian Kes di Tawau, Sabah (Ph.D. thesis, Universiti Sains Malaysia, Pulau Pinang).

Becker, W., \& Watts, M. (2001). Teaching Methods in U.S. Undergraduate economics courses. Journal of Economic Education, 32(3), 269-280.

Faridah, K. (1999). Dasar Pendidikandan Perlaksanaan Kurikulum Ekonomi Asas di Sekolah Menengah: Isudan Cabaran. Seminar Kebangsaan: PendidikanEkonomi di Persimpangan, Kuala Lumpur, November 22-23.

Heck, R., \& Marcoulides, G. (1996). School culture and performance: Testing the invariance of an organizational model. School Effectiveness and School Improvement, 7(1), 76-95. http://dx.doi.org/10.1080/ 0924345960070104

Khoo, Y. Y., \& Kassim, Z. (2005). Pembelajaran Penyelesaian Masalah Secara Kaedah Kolaboratif dengan Pemikiran Kritis dan Kreatif di Kalangan Pelajar-pelajar Tingkatan Enam. Prosiding Seminar Pendidikan JPPG 2005. Shangri-La Inn, 28-30 Ogos, 2005.

Ministry of Education. (2006). Pelan Induk Pembangunan Pendidikan. Rancangan Malaysia Ke-9, 2006-2010.

\section{Copyrights}

Copyright for this article is retained by the author(s), with first publication rights granted to the journal.

This is an open-access article distributed under the terms and conditions of the Creative Commons Attribution license (http://creativecommons.org/licenses/by/3.0/). 